\title{
УДК. 712.253
}

Сm. вик. Кисельов В. М.,

Кафедра Архітектури будівель та споруд Одеська державна академія будівництва та архітектури Ст. вик. Кисельова Г. В.

Кафедра Містобудування Одеська державна академія будівництва та архітектури DOI: 10.32347/2519-8661.2019-20.193516

\section{ФОРМУВАННЯ ПАРКУ-ВИСТАВКИ, ЯК СКЛАДОВОЇ ЧАСТИНИ МІСЬКИХ ПАРКІВ}

Анотація. Стаття присвячена дослідженню спеціалізованих парків (парквиставка) , як важливому компоненту міського парку. В статті дані визначення таким поняттям, як «парк», «міський парк», «сад». Наведена коротка історична довідка виникнення парків та міських садів. Міські парки і сквери поліпшують якість повітря, $є$ середовищем, яке сприяє розвитку різноманітної фауни і флори, скорочують стоки зливних вод та нормалізують міську кліматичну ситуацію. Але окрім створення умов поліпшення здоров'я та якості життя населення за рахунок зростання озеленення міста, доступності отримання соціальних послуг у сфері культури, в тому числі фізкультури і спорту для створення і подальшого розвитку інфраструктури міських парків необхідне залучення туристичних потоків. В статті визначається необхідність створення додаткових компонентів міських парків для залучення відвідувачів.

В статті наведені приклади парків- виставок міст України, дані загальні рекомендації щодо функціонального зонування парку-виставки, а також визначається необхідність покрокового моделювання простору.

Ключові слова. Міський парк, макетування, ландшафтне макетування.

Міста можуть розвиватися тільки за умови збереження природних ресурсів, які забезпечують їхнє економічне зростання та якість життя населення. Численні дослідження доводять, що міські парки та сквери сприяють моральному вихованню людей, дають їм можливості для повноцінного сімейного відпочинку, позитивно впливають на стан здоров'я дітей та підлітків. Сднання жителів міста 3 природою за рахунок інвестицій в благоустрій міських парків та скверів - благородна справа у вирішенні багатьох екологічних проблем. Міські парки та сквери поліпшують якість повітря, є середовищем, яке сприяє розвитку різноманітної фауни і флори, скорочують стоки зливних вод та ослаблюють міську спеку. 
Парк - це «місце». Місце, яке звертається до людини і яке дає людині можливість перебувати в ньому, задовольняти найрізноманітніші потреби: відпочинок, дозвілля, спілкування і усамітнення, пізнання та розвагу. Парк - це місце життя людини.

Міський парк головна визначна пам'ятка кожного культурного міста. Парк в усі часи є місцем відпочинку і проведення дозвілля городян і приїжджих і це доводить його необхідність в місті. Розвиток міського парку зародився в 18 столітті, але перед поняттям «парк», який нікому ще не був відомий, існувало поняття «сад». Сади вперше зустрічаються в Китаї, в місті Сучжоу. Будівництво садів в Китаї почалося ще в 6 столітті до нашої ери.

Сад - це озеленена територія, площею 5 - 10 гектар, що включає насадження, дороги, майданчики, павільйони, естраду, квітники. Призначення саду - короткочасний відпочинок жителів мікрорайону або житлового району. Спочатку в давнину сади були плодовими - утилітарного значення, а після з'явилося поняття «потішного» саду, що означало сад призначений для відпочинку та розвитку.

Вже в 18 столітті в період романтизму з'явилися пейзажні парки. Пейзажний парк - це певний вид садово-паркового мистецтва, що склалось в Англії [1]. Розглядаючи історію становлення парків в Україні, необхідно почати, з поняття - «парк». Термін «парк» увійшов в українську мову з англійської мови і спочатку означав ділянку лісу з алеями, ставками, гаєм і альтанками.

Міський парк - це озеленена відкрита територія призначена для відпочинку, розваг, заходів культурного проведення часу . [1].

Досягнення необхідного рівня якості організації культурного дозвілля, надання якісних послуг населенню міста не можливе без врахування досягнень сучасної індустрії відпочинку. Тому при розробленні програми розвитку парків міста має бути використаний національний та світовий досвід. Окрім створення умов поліпшення здоров'я та якості життя населення за рахунок зростання поліпшення екологічної обстановки, доступності отримання соціальних послуг у сфері культури, в тому числі фізкультури і спорту для створення і подальшого розвитку інфраструктури міських парків необхідно залучення туристичних потоків.

Для залучення туристичних потоків міський парки можна частково перетворювати на парк-виставку.

Парки-виставки - це своєрідні спеціалізовані парки. Такі парки можуть бути розміщені на відокремленій території або, як виставковий сектор на території багатофункціональних парків, прогулянкових і спортивних парків. Експозиції парків - виставок можуть бути різноманітні: вироби промисловості, предмети декоративно-прикладного мистецтва, скульптура i т. ін. Предмети 
експозиції можуть бути представлені, як у натуральному вигляді так і у вигляді макетів. Саме «макетний» спосіб представлення експозиції видається найбільш привабливим для залучення туристичних потоків. Адже макети дають змогу представити в зменшеному вигляді, як пам’ятники архітектури так i цілі експозиції зменшених міст. Макетні експозиції дають змогу відчути себе Гулівером або учасником історичних битв, або відчути себе мандрівником у часі і побачити міста, які існували століття назад ( Рис. 1-4). Також в макетній експозиції можуть бути представлені і ландшафтні макети. (Рис.5). Основним завданням при розміщенні експозиції $є$ сценарний підхід - це створення просторово-часової структури, що складається з об'єктів показу, які пов'язані між собою певними зв'язками в певній послідовності. Формування суспільнорекреаційних просторів із застосуванням сценарного підходу посилює ідентичність місця, що робить його більш виразним і незабутнім.

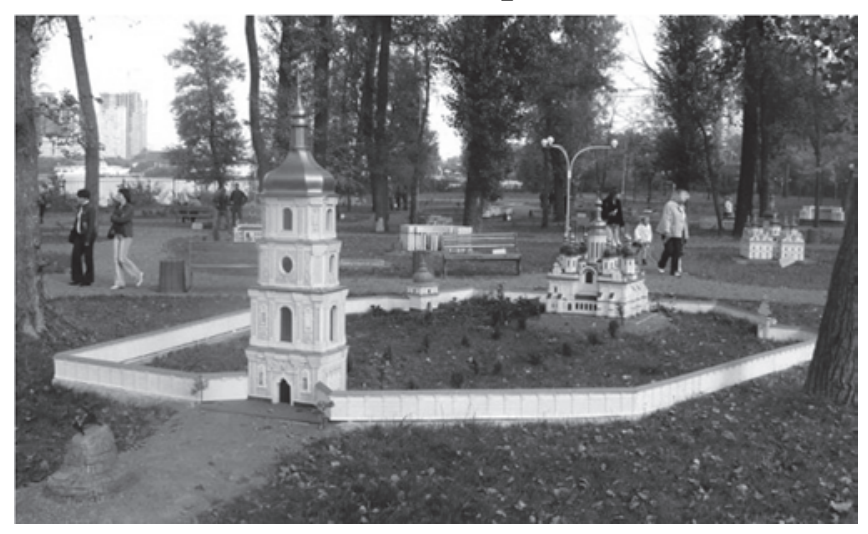

Рис.1. Парк Київ в мініатюрі. 1740 p.

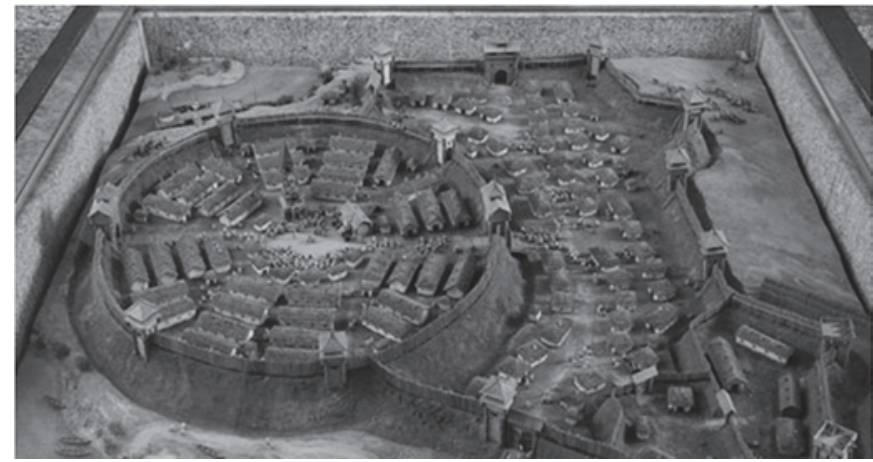

Рис.3 Макет Запорозької Січі XVIII ст.

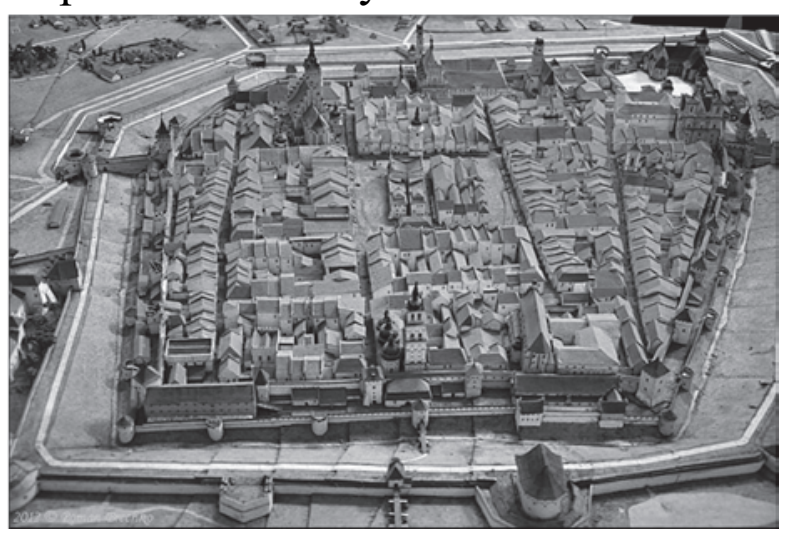

Рис.2. Макет м. Львів станом на

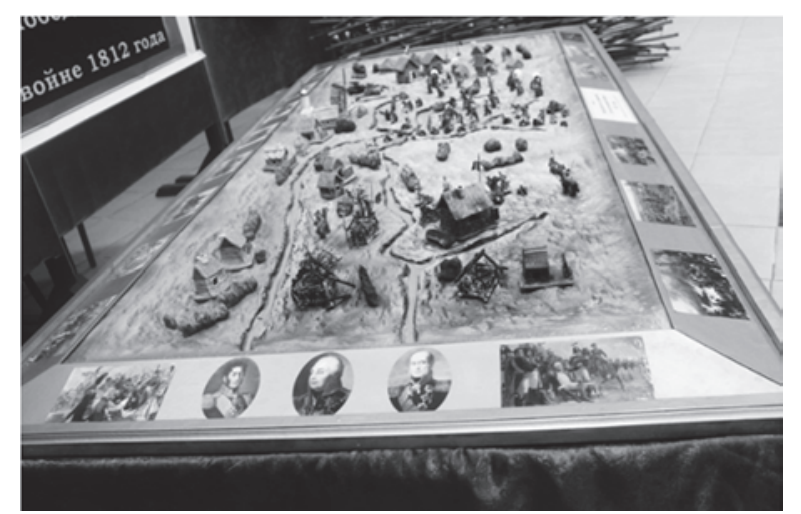

Рис.4 Макет битви при Бородіно. 


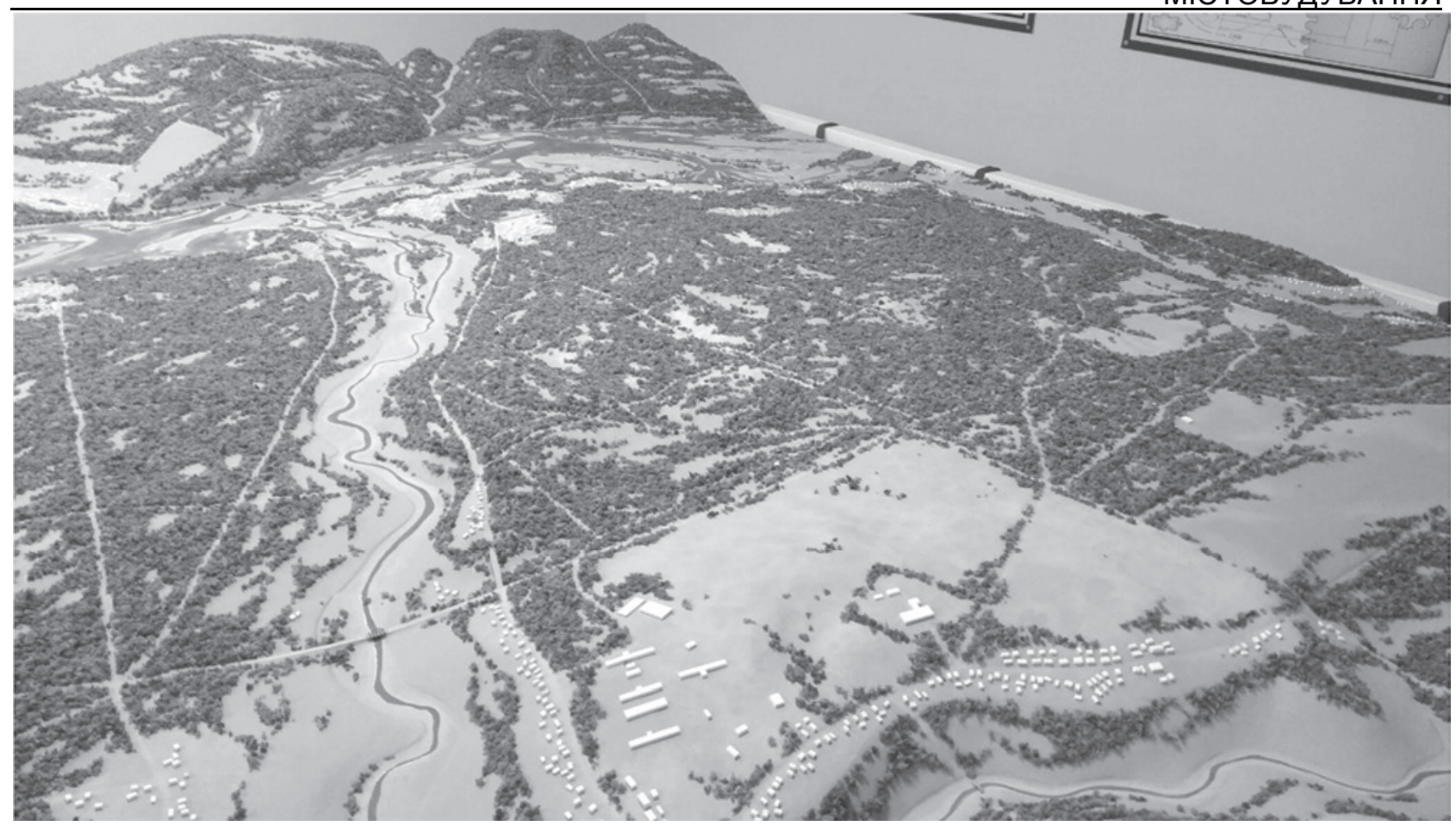

Рис.5. Макет гірської місцевості.

Розміщення парку-виставки в плані міста і архітектурно-планувальне рішення іiі території залежать від характеру і тривалості проведення виставок. Парки-виставки можуть бути стаціонарними, постійно діючими, а нерегулярними, приуроченим до подій, знаменних дат. Функції парків-виставок полягають в ознайомленні 3 досягненнями науки i техніки, промисловості, сільського та лісового господарства, культури і садово-паркового мистецтва. При ландшафтному проектуванні велике значення надається функціональної організації території та визначення центру всієї ландшафтної композиції. Територія парку-виставки, як правило, поділяється на такі зони: зона експозиції, паркова зона i зона розваг - 60...40\%; адміністративна зона - 40...30\%; господарська зона - 2...3\%; зона обслуговування - $12 . . .20 \%$.

Одна з головних задач при проектуванні парку - виставки - організація маршруту, який впливає на рівень візуального сприйняття парку. При організації маршруту враховується сприйняття міського середовища в русі, і предмети розглядаються не тільки в системі просторових координат, а й тимчасових рамок, що дає можливість «режисерувати» взаємодія компонентів середовища, як гармонійного цілого [2]. Маршрут парку орієнтований на постійну зміну вражень. За принципом композиційної побудови маршрут парку складається 3 елементів, які використовуються як в музиці, драматургії, кінематографі, так і в архітектурі. Класичне побудова сюжету складається з зав'язки, розвитку дії, кульмінації і розв'язки. Вхід в парк - початок шляху, зав'язка. Шлях між 
об'єктами показу - розвиток дії. Головний об'єкт показу - це кульмінація. Таким чином, побудова маршруту парку - це покрокове моделювання простору.

\section{Література:}

1. Гостев В. Ф. Проектирование садов и парков / В. Ф. Гостев, Н. Н. Юскевич. - Москва: Стройиздат, 1991. - 340 с.

2. Теодоровский В. С. Объекты ландшафтной архитектуры / В. С. Теодоровский, И. О. Боговая. - Москва: МГУЛ, 2003. - 280 с.

3. Александрова Ю. А. Темати-ческие парки мира / Ю. А. Александрова, О. Н. Сединкина. - Москва: КНОРУС, 2011. - 208 с.

4. Стасюк Н. Г. Макетирование / Н. Г. Стасюк, Т. Ю. Киселева, И. Г. Орлова. Москва: Архитектура, 2010. - 98 с.

Annotation. The article is dedicated to the study of specialized parks (park exhibition) as an important component of a city park. The definition of terms such as "park", "city park", "garden" is given in the article. A brief historical account of the emergence of parks and city gardens is given. The article describes a brief historical background to the occurrence of parks. Urban parks and squares improve air quality, are an environment that contributes to the development of diverse fauna and flora, reduce storm water runoff and normalize the urban climate. But in addition to creating conditions for improving the health and quality of life of the population due to the growing greening of the city, the availability of social services in the cultural field, including physical education and sports to create and further develop the infrastructure of urban parks requires the attraction of tourist flows. The article identifies the need to create additional components of city parks to attract visitors.

The article gives examples of city park exhibitions in Ukraine, provides general recommendations on functional zoning of the exhibition park, and identifies the need for step-by-step space modeling.

Key words. City park, layout, landscape layout.

Аннотация. В статье рассматриваются особенности проектирования парков-выставок как неотъемлемой части городского парка.

Ключевые слова. Городской парк, макетирование, ландшафтное макетирование. 